\title{
Bromatological characteristics of the cowpea in the resistance to Callosobruchus maculatus
}

\author{
Dryelle Sifuentes Pallaoro ${ }^{*}$, Glauce Portela de Oliveira², Dayana Aparecida de Faria ${ }^{1}$, \\ Elisangela Clarete Camili', Maria Aparecida Braga Caneppele'
}

'Federal University of Mato Grosso, Cuiabá, Brazi

2University Center of Varzea Grande, Várzea Grande, Brazil

*Corresponding author, e-mail: dryelle_pallaoro@hotmail.com

\begin{abstract}
This work aimed to relate the bromatological characteristics of four cowpea cultivars to the preference and development of Callosobruchus maculatus. For this, oviposition preference, choice and no-choice tests were performed in four cowpea genotypes: Bico de Ouro, BRS Novaera, BRS Guariba and BRS Tumucumaque. In the no-choice test were determined: viability of eggs, duration of the immature stage, biological cycle, viability of the immature stage, population growth rate, weight per insect, biomass consumption and consumption per insect. As to the chemical composition, the seeds were characterized concerning the crude protein content, ash, neutral detergent fiber, acid detergent fiber and organic matter. In the evaluation, there were significant differences within the genotypes, except for the viability of eggs and consumption per insect. The BRS Novaera genotype presented antixenosis resistance to C. maculatus, whereas the Bico de Ouro, BRS Guariba and BRS Tumucumaque genotypes revealed to be susceptible. The chemical composition of the seeds affects the development of C. maculatus, and the crude protein and ash contents of the seeds without integument present a positive influence over the insect development.
\end{abstract}

Keywords: Bruchid, bean weevil, genetic resistance, Vigna unguiculata

\section{Introduction}

Cowpea (feijão-caupi, feijão-de-corda or feijão-fradinho) (Vigna unguiculata L. Walp.) is a widely cultivated leguminous plant in the semiarid tropics of Africa, Brazil and United States (Barbosa et al., 201 1). In Brazil, cowpea production is an activity of pronounced importance in the Northeast region, in both socioeconomic and nutritional aspects (Teófilo et al., 2008) due to the high protein content of the seeds (Akande, 2007; Frota et al., 2008).

During the whole productive process, the cowpea crop is attacked by several insects. Among the main crop pests, the cowpea weevil Callosobruchus maculatus (Fabr.) holds an elevated harmful potential, especially during the storage, generating qualitative and quantitative losses (Lima et al., 2001)

The infestations by $\mathrm{C}$. maculatus may begin in the field, were the females lay eggs in the surface of grains or seeds (Marsaro Júnior \& Vilarinho, 2011). The larvae of this bruchid, when hatching, penetrate the grains and feed on the internal content. Inside the grains they turn into pupae, and after emergence the adults leave and restart the biological cycle (Melo et al., 2011).

Several essays were developed in the scope of identifying the cowpea genotypes resistant to the attack of C. maculatus (Carvalho et al., 2011, Lima et al., 2001, Marsaro Júnior \& 
Vilarinho 2011, Cajazeira 2000, Melo et al., 2012) without, however, investigating its causes (Castro et al., 2013). In this manner, this study aimed to evaluate the chemical composition of four cowpea cultivars concerning the preference and the development of Callosobruchus maculatus.

\section{Material and Methods}

Four cowpea genotypes were utilized: Bico de Ouro, BRS Novaera, BRS Guariba and BRS Tumucumaque, donated by the Tomazetti seeds company, produced and processed in the municipality of Primavera do Leste, MT state, harvest of 2014/2014. After the receival, the materials were stored in refrigerated chamber at $18^{\circ} \mathrm{C}$ and $60 \%$ of air relative humidity.

The population of $C$. maculatus was multiplied in transparent glass containers, with capacity of $500 \mathrm{~mL}$, closed in the upper portion with stainless screen in order to allow aeration. Cowpea seeds were inserted into the containers, filling up to one fourth of the capacity. Afterwards, adults of $C$. maculatus were inoculated for multiplication, until the quantity of insects was sufficient for the performing of the research. The experiment was performed in a completely randomized design. As for the number of replicates for each test, the evaluations of the genotypes influence on preference, attack and development of C. maculatus and the analyses of the chemical composition presented four and three replicates, respectively.

The evaluation of the cowpea genotypes resistance to the bruchid attack was performed through the oviposition preference, choice and no-choice tests. For the choice test, $30 \mathrm{~g}$ of each genotype seeds were weighed and placed in peripherical containers to the arena, with four replicates. Afterwards, 80 insects were released into the central container, interconnected to the others through plastic cylinders. After 48 hours, the counting of the number of insects in each genotype was performed.

The oviposition preference test (\%) was performed according with Marteleto et al., (2009), in which 16 seeds, four of each genotype, were simultaneously offered for oviposition to a C. maculatus couple. The counting of the eggs occurred in the $10^{\circ}$ day after the infestation, when the eggs presenting a firm white color being were considered as viable, and the hyaline eggs as non-viable. The oviposition preference was calculated as the relation between the total number of eggs and the number of eggs in each genotype.

For the no-choice test, four replicates of $10 \mathrm{~g}$ of each genotype seeds were weighed in analytical balance and placed in plastic containers with perforated cover, inoculating, in each sample, 50 adult insects, randomly selected, without sexing. The insects remained confined for oviposition during 7 days. After the oviposition period, were evaluated:

- viability of eggs (\%): obtained in function of the number of viable eggs, concerning the total number of eggs;

- duration of the immature stage (days): calculated by the formula: $\{[\Sigma$ (daily number of emerged insects $x$ number of days for hatching)]/ total number of emerged insects\};

- biological cycle (days): sum of the elapsed days from the infestation of the samples until the day of emergence of the last adult insect, representing the lifetime between the egg stage and the adult stage:

- viability of the immature stage (\%): calculated in function of the total of emerged insects, concerning the number of viable eggs (Lima et al., 2001);

- emergence of adults: daily counting of the number of emerged insects, and, after the counting, the insects were slaughtered and conserved in alcohol $70 \%$ until the end of emergence, for later evaluations.

- population growth rate (ri), calculated through the equation $r i=\left[\ln \left(N_{f} / N_{0}\right) / \Delta T\right]$, in which $N_{f}=$ final number of insects; $N_{0}=$ initial number of insects; and $\Delta T=$ time elapsed (number of days in which the essay was executed);

- weight per insect (mg insect ${ }^{-1}$ ): ratio between the weight and the total number of emerged insects. For obtaining the mass of insects, alcohol $70 \%$ was drained and dried in ambient conditions for 48 hours, from the samples originated from the daily emergence test.

- biomass consumption (\%) determined by the equation $B C=[(I D M-F D M) / I D M)] * 100$, in which $B C=$ biomass consumption, IDM = initial 
dry mass and FDM = final dry mass;

- consumption per insect (mg insect-1) obtained through the ration between the dry mass consumed, after humidity correction, and the number of emerged insects. For this calculation, the initial water content of the seeds was determined in drying oven at $105^{\circ} \mathrm{C}$ for 24 hours.

As to the chemical composition of the seeds, for crude protein were analyzed full seeds with no integument. For the quantification of ash, insoluble fiber in neuter detergent (NDF), insoluble fiber in acid detergent (ADF) and organic matter, were utilized seeds without integument in order to quantify the constituent components of the seeds consumed by the C. maculatus during the larval stage.

For the determination of the chemical composition, the whole seeds or the seeds without integument were powdered, sieved (1 $\mathrm{mm}$ mesh) and conserved in freezer until the performing of the analyses. The samples were evaluated as to the crude protein content through the quantification of total nitrogen, by the Kjedahl method (Detmann et al., 2012 b) - ash (Souza et al., 2012), insoluble fiber in neutral detergent (Detmann et al., 2012 a), insoluble fiber in acid detergent (Detmann et al., 2012 a) and organic matter (Souza et al., 2012).

At the end, the data were subjected to analysis of variance, and when significant, the means were compared through Tukey's test $(p>0.05)$. The Pearson correlation analysis $(P>$ $0.05)$ was also performed within the variables, with later classification as very strong $(|r|>0.8)$, strong $(0,6<|r|<0.8)$, moderate $(0.4<|r|<0.6)$, weak $(0.2<|r|<0.4)$ and negligible $(|r|<0.2)$. The correlation coefficients were inserted during the discussion, not presented in the form of table.

\section{Results and Discussion}

In the preference test with choice, the Bico de Ouro genotype presented the highest attractivity to the C. maculatus (Table 1). This might have occurred through olfactory stimulus, since that in the utilized arena the insects did not possess visual contact with the seeds. The genotype with lowest attractivity was the BRS Novaera, with $10 \%$ of the total.

Table 1. Choice test, oviposition preference, viability of eggs, duration of the immature stage, biological cycle, viability of the immature stage, population growth rate, weight per insect, biomass consumption and consumption per insect of Callosobruchus maculatus in different cowpea genotypes (Vigna unguiculata).

\begin{tabular}{|c|c|c|c|c|c|}
\hline Genotypes & Bico de Ouro & $\begin{array}{c}\text { BRS } \\
\text { Novaera }\end{array}$ & BRS Guariba & $\begin{array}{c}\text { BRS } \\
\text { Tumucumaque }\end{array}$ & CV (\%) \\
\hline Choice test (\%) & $38.0 \mathrm{a}$ & $10.0 \mathrm{~d}$ & $24.0 \mathrm{C}$ & $28.0 \mathrm{~b}$ & 4.6 \\
\hline Oviposition preference (\%) & $33.2 \mathrm{ab}$ & $4.2 \mathrm{C}$ & $37.4 a$ & $27.6 \mathrm{~b}$ & 12.6 \\
\hline Viability of eggs (\%) & 87.9 Ns & 99.8 & 90.3 & 89.2 & 6.4 \\
\hline Duration of the Immature stage (days) & $29.3 \mathrm{~b}$ & $29.9 \mathrm{a}$ & $29.6 \mathrm{ab}$ & $29.9 \mathrm{a}$ & 0.7 \\
\hline Biological cycle (dias) & $40.2 a b$ & $44.0 \mathrm{~b}$ & $38.0 \mathrm{a}$ & $40.5 \mathrm{ab}$ & 4.9 \\
\hline Viability of the immature stage (\%) & $77.6 \mathrm{ab}$ & $60.7 \mathrm{~b}$ & $76.8 \mathrm{ab}$ & $85.7 \mathrm{a}$ & 14.4 \\
\hline Population growth rate & $0.049 a$ & $0.032 b$ & $0.051 \mathrm{a}$ & $0.049 a$ & 8.2 \\
\hline Weight per insect (mg insect-1) & $2.05 \mathrm{~b}$ & $2.32 \mathrm{a}$ & $2.04 \mathrm{~b}$ & $1.85 \mathrm{~b}$ & 5.3 \\
\hline Biomass consumption (\%) & $52.2 \mathrm{a}$ & $30.9 \mathrm{~b}$ & $53.1 \mathrm{a}$ & $52.9 \mathrm{a}$ & 7.2 \\
\hline Consumption per insect (mg insect ${ }^{-1}$ ) & 14.6 NS & 16.2 & 15.8 & 14.6 & 8.5 \\
\hline
\end{tabular}

NS: not significant; $C V$ : coefficient of variation.

Means followed by the same letter, on the line, do not differ by Tukey's test $(p>0.05)$.

The lowest oviposition preference was verified in the BRS Novaera genotype, in the highest in the BRS Guariba and Bico de Ouro genotypes (Table 1). Based on the choice and oviposition preference tests it was possible to characterize the BRS Novaera genotype as carrier of non-preference resistance or antixenosis, that is, when the genotype generates the lowest preference for feeding or oviposition. Lima et al. (2001), by evaluating Vigna unguiculata, also characterize the genotypes with low oviposition percentage as carriers of non-preference resistance.

This non-preference of oviposition might be related to the physical characteristics of the integument of the BRS Novaera, a genotype characterized for presenting clear coloring, matte and rough seeds. Nwanze et al. (1975) 
report that $C$. maculatus insects prefer seeds with soft and smooth integument for oviposition, in relation to the harsh and rough homologues, as ratified by Lima et al. (2001) in their studies with C. maculatus.

Concerning the viability of eggs, there was no significant difference within genotypes. As to the duration of the immature stage, there was difference within the materials, and in the Bico de Ouro genotype the egg-adult development lapse was smaller. The amplitude of the data on the duration of the immature stage, within genotypes, was 0,6 , therefore inferior to one day (Table 1). A similar behavior was reported by Lima et al. (2001), when evaluating the attack of $C$. maculatus to the cowpea, in which the maximum difference in the duration of the immature stage within materials was one day.

For the variable biological cycle, the insects developed in the BRS Novaera genotype demanded a longer time to complete the cycle (Table 1). In all genotypes, the emergence of adults started at 27 days after infestation (DAI). For the BRS Novaera, the lapse extended until the $44^{\circ}$ DAI. In this genotype the peak of maximum emergence occurred in the $29^{\circ} \mathrm{DAl}$, with 44 emerged insects, an inferior value to the remaining materials (Figure 1).

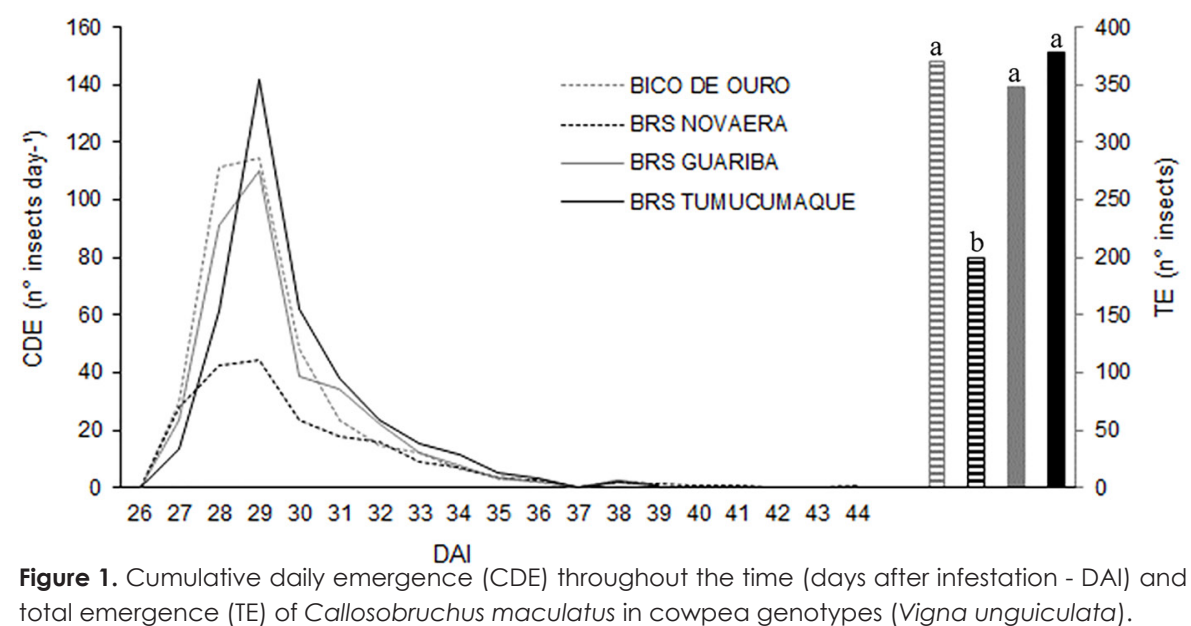

The peak of maximum adult emergence occurred at 29 DAl in the BRS Tumucumaque genotype, with 141 insects (Figure 1). The total emergence of insects was superior in the BRS Tumucumaque, Bico de Ouro and BRS Guariba genotypes in comparison to the BRS Novaera, with, 379, 370, 348 and 199 emerged insects, respectively. In this manner, the BRS Novaera genotype reduced the total emergence and extended the emergence lapse of $C$. maculatus, pointing a possible resistance, since that when the insects demand a higher time for completing the immature stage, a non-preference resistance is suggested for feeding and/or antibiosis (Lara, 1991). Similarly, Medeiros et al. (2017), studying different cowpea genotypes infested with $C$. maculatus, reported a likely resistance through antibiosis in the BRS Urubuquara genotype. In the viability of the adult stage, the lowest percentage occurred in the BRS Novaera genotype, in which $60.7 \%$ of the viable eggs generated adult insects. The mortality of $39.3 \%$ of the developing insects suggests the occurrence of mortality due to antibiosis in the larval stage. This mortality might be related to the existence of chemical substances present in the seeds, which are unfavorable to the bruchid. Lima et al. (2001) suggest that the high mortality is associated to chemical substances in the grains, which are unfavorable to the larval development of $C$. maculatus.

As to the population growth rate, which relates the initial number of inoculated insects to the final number of emerged insects in a determined time lapse, the lowest value occurred in the BRS Novaera genotype (Table 1). The low population growth rate in relation to the remaining genotypes correlates with the data of viability of the immature stage, previously cited, and corroborates with Medeiros et al. 
(2017), who, evaluating the que BR 17 Gurguéia genotype, verified that his genotype presented lowest adult emergence and lowest viability of the immature stage, suggesting to be inadequate for the development of $C$. maculatus, expressing resistance through antibiosis and/or nonpreference for feeding.

The heavier insects were those developed in the BRS Novaera genotype (Table 1). When correlating the average weight to the consumed dry mass per insect, there is a strong and positive linear relation within the variables $(\rho=0,660)$, demonstrating that the increase in weight is associated to a higher biomass consumption per insect.

Another item to be observed refers to the competition of the larvae for food, since that in the BRS Novaera genotype there was lower oviposition and viability of the immature stage, resulting in a lower quantity of larvae feeding in one same seed. The variables viability of the immature stage and total emergence, when correlated with the weight per insect, were significant, negative, very strong and strong $(\rho=-$ 0.932 and $\rho=-0.782$ ) respectively.

The decrease in the viability of the immature stage, and, consequently, in the emergence of adult insects was accompanied by the increase in the weight of the individuals. Possibly, the reduction in the number of larvae generated an increase in the weight of the adult individuals through the minimization of food competition. By evaluating populations of Mexican bean weevil, Marteleto et al. (2009) observed that variations in the size of the adult insect are intimately linked to the offer of food resources.

In the Bico de Ouro, BRS Guariba and BRS Tumucumaque genotypes, the biomass consumption was superior to $50 \%$ of the initial dry mass, and in the BRS Novaera the consumption was $30 \%$ (Table 1). In practical terms, by relating the variables biomass consumption and biological cycle, it might be observed that at every 40 days there is a new generation of insects, which consume half of the dry mass, what represents a considerable economic loss.

By correlating the biomass consumption to the viability of the adult stage, there is a positive and very strong linear relation $(\rho=0.811)$. The increase in the consumption is related to the higher number of developing larvae in the seed. On the other hand, the correlation between the variables: viability of the immature stage and consumed dry mass per insect was negative and strong $(\rho=-0.758)$, therefore, the increment in the quantity of developing larvae (viability of the immature stage) was accompanied by the larvae competition for food. Carvalho et al. (2011), when testing different genotypes, did not find a significant correlation between the number of larvae and the dry mass consumption of seeds by the bean weevil as a whole or individually, a different result from the obtained in this study.

For the bruchid Zabrotes subfasciatus, the increase in the larval density implied in a reduction of weight gain even in bean grains with higher amount of food and available space, suggesting a competition process (Oliveira et al., 2015). In internal primary, granivore insects, that spend life inside the grain, there is competition for the limited resources in the immature stage. In this system, the individual is unable to avoid the competition with the co-specific, since that several eggs are deposited and hatched in the same grain (Colegrave, 1994).

Among the hypotheses of this work, it was presupposed that the Bico de Ouro genotype would possess a quantitatively superior bromatological constitution, since that in the preference evaluations (Table 1) it obtained a higher insect attractivity. However, in the whole seeds, the highest crude protein percentage occurred in the BRS Guariba genotype - whole seeds - and in the BRS Tumucumaque - seeds without integument (Table 2).

By comparing the protein content of the whole seeds in relation to the seeds without integument, it is possible to observe that the elevated nitrogen portion participates in the cowpea integument constitution. In the seeds without integument, the correlation between the crude protein content and some entomological variables were positive and significant, thus, higher crude protein contents are related to the increase in the consumption per insect $(\rho=0.755)$, viability of eggs $(\rho=0.810)$, population growth rate $(\rho=0.590)$ and total emergence $(\rho=0.748)$. 
However, the correlation was negative for the average weight per insect $(\rho=-0.839)$ and biological cycle $(\rho=-0.771)$, being that the reduction in the average weight per insect might be related to the presence of anti-nutritional factors in the seeds.

In studies utilizing computerized axial scanning, it was possible to observe that the feeding C. maculatus occurs in a differentiated manner when cultivated in resistant or susceptible cowpea seeds, occurring, in the resistant seeds, a region that possesses a more intense negative effect over the insect, which, by its turn, avoids the specific area for feeding (Tarver et al., 2006). In this manner, the genotypes that present toxic substances might generate deleterious effects over themselves.

Therefore, the differences in the attractivity and development of C. maculatus might be related to the quantitative and qualitative bromatological characteristics, including the presence of allelochemicals, inhibitors and toxic substances, not evaluated in this research.

Concerning the ash content in the seeds without integument, values from 3.3 to $3.8 \%$ (Table 2) were observed. The highest value occurred in the Bico de Ouro (3.8\%), genotype with highest attack preference. The correlation was significant, very strong and strong within the ash content and the choice preference entomological variables $(\rho=0.849)$, total emergence $(\rho=0.610)$, viability of the immature stage $(\rho=0.717)$ and biological cycle $(\rho=-0.709)$, thus, the ash content positively influences in the larval development and in the emergence of adults of C. maculatus.

The ash content represents the mineral fraction of the seed, including nutrients, and might present variations in the order of 2.6 (Frota et al., 2008) and 4.2\% (labal et al., 2006) in cowpea seeds or grains.

As to the fiber content, in the seeds without integument, the higher percentages occurred in the BRS Tumucumaque, BRS Novaera and Bico de Ouro genotypes for NDF, whereas for the ADF there was no significant difference within genotypes (Table 2). Within the fiber components, there is the NDF fraction composed by cellulose, hemicellulose, lignin and lignified protein, and the ADF fraction, which corresponds to the less digestible fraction of the cell wall, mainly constituted of lignocellulose, that is, cellulose and lignin (Rocha-Olivieri et al., 2012). For the fiber contents (NDF and ADF) there was no significant correlation of these with the entomological variables. In the same manner, for the content of organic matter, the correlations were not significant, and thus the quantity of organic matter is not linearly associated to the development alterations of C. maculatus. The highest content of organic matter was observed in the BRS Guariba genotype.

Therefore, the bromatological characteristics of the cowpea genotypes do alter the multiplication and the development of C. maculatus. The variations as to the insect preference for specific genotypes might be related to the types of seed-constituent proteins and the presence of antinutritional factors. In this manner, detailed studies for the identification of the bromatological profile of the seeds are recommended for the establishment of a clear relation between the quantity and the quality of nutrients and the resistance of cowpea genotypes to C. maculatus.

Table 2. Bromatological characteristics of whole seeds (WS) and seeds without integument (SWI) of cowpea genotypes (Vigna unguiculata).

\begin{tabular}{lrrrrrrrrr}
\hline \multicolumn{1}{c}{ Genótipos } & \multirow{2}{*}{ Bico de Ouro } & \multicolumn{2}{c}{$\begin{array}{c}\text { BRS } \\
\text { Novaera }\end{array}$} & $\begin{array}{c}\text { BRS } \\
\text { Guariba }\end{array}$ & $\begin{array}{c}\text { BRS } \\
\text { Tumucumaque }\end{array}$ & $\begin{array}{c}\text { CV } \\
(\%)\end{array}$ \\
\hline Crude protein: WS (\%) & 33.0 & $\mathrm{~d}$ & 35.6 & $\mathrm{~b}$ & 35.9 & $\mathrm{a}$ & 34.8 & $\mathrm{c}$ & 0.2 \\
\hline Crude protein: SWT (\%) & 24.9 & $\mathrm{~b}$ & 24.8 & $\mathrm{~b}$ & 27.9 & $\mathrm{a}$ & 27.9 & $\mathrm{a}$ & 0.2 \\
\hline Ash: SWT (\%) & 3.8 & $\mathrm{a}$ & 3.3 & $\mathrm{c}$ & 3.3 & $\mathrm{c}$ & 3.7 & $\mathrm{~b}$ & 2.1 \\
\hline Neutral detergent fiber: SWT (\%) & 38.3 & $\mathrm{ab}$ & 40.8 & $\mathrm{a}$ & 34.1 & $\mathrm{~b}$ & 43.4 & $\mathrm{a}$ & 5.2 \\
\hline Acid detergent fiber: SWT (\%) & 2.6 & $\mathrm{Ns}$ & 2.6 & & 2.7 & & 3.2 & & 10.7 \\
\hline Organic matter: SWT (\%) & 91.5 & $\mathrm{~b}$ & 91.4 & $\mathrm{~b}$ & 92.2 & $\mathrm{a}$ & 92.1 & $\mathrm{a}$ & 0.2 \\
\hline NS: not significant; CV: coefficient of variation. \\
Means followed by the same letter, on the line, do not differ by Tukey's test $(\mathrm{p}>0.05)$.
\end{tabular}




\section{Conclusions}

1. The bromatological constitution of the seeds affects the development of C. maculatus.

2. The crude protein and ash content of the seeds without integument positively influences in the development of C. maculatus.

3. The BRS Novaera genotype presents a possible resistance through antixenosis and antibiosis to Callosobruchus maculatus.

4. The Bico de Ouro, BRS Guariba and BRS Tumucumaque genotypes revelaed to be susceptible to C. maculatus.

\section{Acknowledgments}

To the Tomazetti seeds company for the donation of the seeds utilized in the experiment.

\section{References}

Akande, S.R. 2007. Genotype by environment interaction for cowpea seed yield and disease reactions in the forest and derived savanna agro-ecologies of southwest Nigeria. AmericanEurasian Journal of Agricultural \& Environmental Science 2:163-168.

Barbosa, D.R.S., Fontes, L.S., Melo, R.S., Rocha, L.I.R., Lima, M.S. 2011 . Resistência de genótipos de feijão-caupi ao ataque de Zabrotes subfasciatus (Boheman, 1833) (Coleoptera: Chrysomelidae: Bruchinae). Revista Verde 6:70-77.

Carvalho, R.O., Lima, A.C.S., Alves, J.M.A. 2011. Resistência de genótipos de feijão-caupi ao Callosobruchus maculatus (Fabr.) (Coleoptera: Bruchidae). Revista Agro@mbiente On-line 5:5056.

Castro, M.J.P., Baldin, E.L.L., Cruz, P.L., Souza, C.M., Silva, P.H.S. 2013. Characterization of cowpea genotype resistance to Callosobruchus maculatus. Pesquisa Agropecuária Brasileira 48:1201-1209.

Colegrave, N. 1994. Game theory models of competition in closed systems: asymmetries in fighting and competitive ability. Oikos 71:499-505.

Detmann, E., Valente, T.N.P., Berchielli, T.T. 2012. Avaliação da fibra insolúvel em detergente neutro e da fibra insolúvel em detergente ácido. In: Detmann et al. (eds.). Métodos para análise de alimentos. Suprema, Visconde do Rio Branco, Brasil. p. 93-111(a).

Detmann, E., Queiroz, A.C., Cabral, L.S. 2012. Avaliação do nitrogênio total (proteína bruta) pelo método de Kjeldahl. In: Detmann et al. (eds.) Métodos para análise de alimentos. Suprema, Visconde do Rio Branco, Brasil. p. 51-68 (b).
Frota, K.M.G., Soares, R.A.M., Arêas, J.A.G. 2008. Composição química do feijão caupi (Vigna unguiculata L. Walp), cultivar BRS-Milênio. Ciência e Tecnologia de Alimentos 28:470-476.

Iqbal, A., Khalil I.A., Ateeq, N.; Khan, M.S. 2006. Nutritional quality of important food legumes. Food Chemistry 97:331-335.

Lara, F.M. Princípios de resistência de plantas a insetos. Ícone, São Paulo, Brasil, 1991. 336p.

Souza, M.A., Valadares Filho, S.C., Detmann, E. 2012. Avaliação das cinzas ou matéria mineral. In: Detmann et al. (eds.) Métodos para análise de alimentos. Suprema, Visconde do Rio Branco, Brasil. p. 41-50.

Lima, M.P.L., Oliveira, J.V., Barros, R., Torres, J.B. 2001. Identificação de Genótipos de Caupi Vigna unguiculata (L.) Walp. Resistentes a Callosobruchus maculatus (Fabr.) (Coleoptera: Bruchidae). Neotropical Entomology 30:298-295.

Marteleto, P.B., Lomônaco, C., Kerr, W.E. 2009. Respostas fisiológicas, morfológicas e comportamentais de Zabrotes subfasciatus (Boheman) (Coleoptera: Bruchidae) associadas ao consumo de diferentes variedades de feijão (Phaseolus vulgaris). Neotropical Entomology 38:178-185.

Marsaro Júnior, A.L., Vilarinho, A.A. 2011. Resistência de cultivares de feijão-caupi ao ataque de Callosobruchus maculatus (Coleoptera: Chrysomelidae: Bruchinae) em condições de armazenamento. Revista Acadêmica 9:51-55.

Medeiros, W.R., Silva, J.D.C., Silva, P.R.R., Girão Filho, J.E., Padua, L.E.M., França, S.M. 2017. Resistência de genótipos de feijão-caupi [Vigna unguiculata (L.) Walp.] ao Ataque do Caruncho Callosobruchus maculatus (Fabr.) (Coleoptera: Chrysomelidae). EntomoBrasilis 10: 19-25.

Melo, A.F., Fontes, L.S., Barbosa, D.R.S., Araújo, A.A.R., Sousa, E.P.S., Soares, L.L.L., Silva, P.R.R. 2012. Resistência de genótipos de feijão-caupi ao ataque de Callosobruchus maculatus (Fabr., 1775) (Coleoptera: Chrysomelidae: Bruchinae). Arquivos do Instituto Biológico 79:425-429.

Melo, B.A., Oliveira, S.R., Leite, D.T., Barreto, C.F., Silva, H.F. 2011 . Inseticidas botânicos no controle de pragas de produtos armazenados. Revista verde 6:1-10.

Nwanze K.F., Horber E., Pitts C.W.P. 1975. Evidence of ovipositional preference of Callosobruchus maculatus for cowpea varieties. Environmental Entomology 4:409-412.

Oliveira, S.O.D., Rodrigues, A.S., Vieira, J.L., RosiDenadai, C.A., Guedes, N.M.P., Guedes, R.N.C. 
Pallaoro et al. (2018) / Bromatological characteristics of...

2015. Bean type modifies larval competition in Zabrotes subfasciatus (Chrysomelidae: Bruchinae). Journal of Economic Entomology 108:2098-2106.

Rocha-Olivieri, C.M., Conti-Silva, A.C., Lopes-Filho, J.F. 2012. Avaliação das características físicoquímicas e microbiológicas dos componentes fibrosos obtidos da moagem úmida de grãos de milho. Revista Inst. Adolfo Lutz 71:728-732.

Souza, M.A., Valadares Filho, S.C., Detmann, E. 2012. Avaliação das cinzas ou matéria mineral. In: Detmann et al. (eds.) Métodos para análise de alimentos. Suprema, Visconde do Rio Branco, Brasil. p. 41-50.

Tarver, M.R., Shade, R.E., Tarver, R.D., Liang, Y., Krishnamurthi, G., Pittendrigh, B.R., Murdock, L.L. 2006. Use of micro-CAT scans to understand cowpea seed resistance to Callosobruchus maculatus. Entomologia Experimentalis et Applicata 118:33-39.

Teófilo, E.M., Dutra, A.S., Pitombeira, J.B., Dias, F.T.C., Barbosa, F.S. 2008. Potencial fisiológico de sementes de feijão caupi produzidas em duas regiões do Estado do Ceará. Revista Ciência Agronômica 39:443-448. 